\title{
DISPATCHES
}

\section{Co-infection with Legionella and SARS-CoV-2, France, March 2020}

Camille Allam, Alexandre Gaymard, Ghislaine Descours, Christophe Ginevra, Laurence Josset, Maud Bouscambert, Laetitia Beraud, Marine Ibranosyan, Camille Golfier, Arnaud Friggeri, Bruno Lina, Christine Campèse, Florence Ader, Sophie Jarraud; COVID-19 diagnosis HCL consortium ${ }^{1}$

We describe a March 2020 co-occurrence of Legionnaires' disease (LD) and coronavirus disease in France. Severe acute respiratory syndrome coronavirus 2 co-infections were identified in 7 of 49 patients from LD case notifications. Most were elderly men with underlying conditions who had contracted severe pneumonia, illustrating the relevance of co-infection screening.

The coronavirus disease (COVID-19) pandem1 ic spread to France in mid-February 2020 (1). Co-infections have been described in patients with COVID-19 (2,3), but only 3 co-infections with Legionella have been reported (4-6). We report 7 cases of severe acute respiratory syndrome coronavirus 2 (SARS-CoV-2) and Legionnaires' disease (LD) co-infections in France during March 2020.

\section{The Study}

In France, LD surveillance is based on mandatory notifications to Santé Publique France, the national public health agency. To evaluate LD and COVID-19 co-occurrence, we retrospectively studied all LD case notifications with symptom onset during March 2020 and included cases in which patients had clinical or radiologic signs of pneumonia combined with Legionella culture, positive Legionella PCR from broncho-pulmonary secretions, or positive Legionella pneumophila serogroup 1 urinary antigen test (UAT) results. There were $65 \mathrm{LD}$ case notifications in March 2020 compared with 79 in March 2019. To evaluate

Author affiliations: Hospices Civils de Lyon, Lyon, France (C. Allam, A. Gaymard, G. Descours, C. Ginevra, L. Josset, L. Beraud, M. Ibranosyan, C. Golfier, A. Friggeri, B. Lina, F. Ader, S. Jarraud); Université de Lyon, Lyon (C. Allam, A. Gaymard, G. Descours, C. Ginevra, L. Josset, M. Ibranosyan, B. Lina, F. Ader, S. Jarraud); Centre International de Recherche en Infectiologie, Lyon (C. Allam, A. Gaymard, G. Descours, C. Ginevra, L. Josset, B. Lina, F. Ader, S. Jarraud); Santé Publique France, Saint-Maurice, France (C. Campèse) the number of UATs, which are performed in $96 \%$ of LD cases (7), we contacted the 59 reporting laboratories (in 47 cities), 33 of which sent the relevant data. The number of UATs increased 2.5-fold (interquartile range: 1.6-2.8) from 3,203 in March 2019 to 8,004 in March 2020. Data obtained from 6 major UAT suppliers indicated a similar 2.1-fold (interquartile range 1.52-14.8-fold) increase in tests sold to laboratories in France, from 33,378 in March 2019 to 65,072 in March 2020. Despite these increases, the number of LD case notifications was 18\% lower in March 2020 than in March 2019.

Among the 65 patients from the case notifications, 49 were tested for both LD and COVID-19 and 12 for LD only; no information was available for 4 . The frequency of proven LD/COVID-19 co-infection was $14.3 \%(7 / 49)$. This finding may be an overestimate because COVID-19 incidence was $<5$ cases $/ 100,000$ persons in the region of residence of the 16 patients not tested at the time of symptom onset; actual coinfection frequency could be from $10.8 \%(7 / 65)$ to $14.3 \%(7 / 49)$.

Most patients (4/7) with co-infection lived in the Grand Est region, the area in France with the most COVID-19 cases during the study period and a region that usually reports a high number of LD cases. Median patient age was 72 years (range 37-83 years); male-to-female ratio was 6:1 (Table), higher than for the overall COVID-19-infected population (8). Of interest, the male-to-female ratio for LD has elsewhere been reported as $\approx 3: 1(7)$, similar to the ratio observed in the LD-positive/COVID-19-negative cases.

At hospital admission, co-infected patients had more underlying conditions; $6(86 \%)$ of 7 patients had $\geq 1$, compared with 25 (60\%) of 42 LD-positive/ COVID-19-negative patients (Table). For cardiovascular diseases, the proportions were 6 of 7 among co-infected and 1 of 42 among LD-positive/COVID-19-negative patients. Sources of LD exposure 
Table. Patient demographics, underlying conditions, and risk exposures for patients with LD, with and without co-occurring COVID-19, France, 2020*

\begin{tabular}{|c|c|c|c|c|c|c|c|c|c|}
\hline \multirow[b]{2}{*}{ Patient no. } & \multirow{2}{*}{$\begin{array}{c}\text { LD-positive, } \\
\text { coVID-19-negative }\end{array}$} & \multirow{2}{*}{$\begin{array}{c}\text { LD- and } \\
\text { covID-19-positive }\end{array}$} & \multicolumn{7}{|c|}{ LD- and COVID-19-positive patient details } \\
\hline & & & 1 & 2 & 3 & 4 & 5 & 6 & 7 \\
\hline \multicolumn{10}{|l|}{ Demographics $\dagger$} \\
\hline Sex & M:F ratio $23: 18$ & M:F ratio $6: 1$ & M & M & M & $\mathrm{F}$ & M & $\mathrm{M}$ & M \\
\hline Age, y & $\begin{array}{l}\text { Median (range), } \\
67(36-96)\end{array}$ & $\begin{array}{c}\text { Median (range), } 72 \\
(37-83)\end{array}$ & 72 & 71 & 71 & 83 & 73 & 73 & 37 \\
\hline ICU admission & $10 / 31(32)$ & $7 / 7(100)$ & $\mathrm{Y}$ & $\mathrm{Y}$ & $\mathrm{Y}$ & $\mathrm{Y}$ & $\mathrm{Y}$ & $\mathrm{Y}$ & $\mathrm{Y}$ \\
\hline \multicolumn{10}{|l|}{ Outcome† } \\
\hline Recovered & $7 / 42(17)$ & $1 / 7(14)$ & $\mathrm{N}$ & $\mathrm{N}$ & $\mathrm{N}$ & $\mathrm{Y}$ & $\mathrm{N}$ & $\mathrm{N}$ & $\mathrm{N}$ \\
\hline Death & $3 / 42(7)$ & $2 / 7(29)$ & $\mathrm{N}$ & $\mathrm{N}$ & $\mathrm{Y}$ & $\mathrm{N}$ & $\mathrm{N}$ & $\mathrm{Y}$ & $\mathrm{N}$ \\
\hline Ongoing disease & $32 / 42(76)$ & $4 / 7(71)$ & Y & $\mathrm{Y}$ & $\mathrm{N}$ & $\mathrm{N}$ & $Y$ & $\mathrm{~N}$ & $\mathrm{Y}$ \\
\hline \multicolumn{10}{|l|}{ Underlying conditions } \\
\hline Corticotherapy $\ddagger$ & $1 / 42(2)$ & 2/7 (29) & $\mathrm{Y}$ & $\mathrm{Y}$ & $\mathrm{N}$ & $\mathrm{N}$ & $\mathrm{N}$ & $\mathrm{N}$ & $\mathrm{N}$ \\
\hline Other immunosuppression $\ddagger$ & $5 / 42(12)$ & $0 / 7(0)$ & $\mathrm{N}$ & $\mathrm{N}$ & $\mathrm{N}$ & $\mathrm{N}$ & $\mathrm{N}$ & $\mathrm{N}$ & $\mathrm{N}$ \\
\hline Smoking $\ddagger$ & $15 / 42(36)$ & $2 / 7$ (29) & $\mathrm{N}$ & Y & Y & $\mathrm{N}$ & $\mathrm{N}$ & $\mathrm{N}$ & $\mathrm{N}$ \\
\hline Cardiovascular diseases & $1 / 42(2)$ & $6 / 7(90)$ & $\mathrm{Y}$ & $\mathrm{Y}$ & $\mathrm{Y}$ & $\mathrm{Y}$ & $Y$ & $\mathrm{Y}$ & $\mathrm{N}$ \\
\hline Chronic respiratory disease & $4 / 42$ (10) & $1 / 7(14)$ & $\mathrm{N}$ & Y & $\mathrm{N}$ & $\mathrm{N}$ & $\mathrm{N}$ & $\mathrm{N}$ & $\mathrm{N}$ \\
\hline Chronic renal insufficiency & $1 / 42(2)$ & $1 / 7(14)$ & $\mathrm{N}$ & $\mathrm{N}$ & $\mathrm{N}$ & $\mathrm{N}$ & $\mathrm{N}$ & $Y$ & $\mathrm{~N}$ \\
\hline Diabetes $\ddagger$ & $10 / 42(24)$ & $2 / 7(29)$ & $\mathrm{N}$ & $\mathrm{Y}$ & $\mathrm{N}$ & $\mathrm{N}$ & Y & $\mathrm{N}$ & $\mathrm{N}$ \\
\hline Hemopathy or cancer $\ddagger$ & $3 / 42(7)$ & $2 / 7(29)$ & $\mathrm{Y}$ & $\mathrm{N}$ & $\mathrm{Y}$ & $\mathrm{N}$ & $\mathrm{N}$ & $\mathrm{N}$ & $\mathrm{N}$ \\
\hline$\geq 1$ underlying condition & $25 / 42(60)$ & $6 / 7(86)$ & $\mathrm{Y}$ & $\mathrm{Y}$ & $\mathrm{Y}$ & $\mathrm{Y}$ & $Y$ & $\mathrm{Y}$ & $\mathrm{N}$ \\
\hline \multicolumn{10}{|l|}{ Exposures§ } \\
\hline Hospital‡ & $1 / 42(2)$ & $2 / 7(0)$ & $\mathrm{Y}$ & $\mathrm{Y}$ & $\mathrm{N}$ & $\mathrm{N}$ & $\mathrm{N}$ & $\mathrm{N}$ & $\mathrm{N}$ \\
\hline Nursing homeł & $2 / 42(5)$ & $0 / 7(0)$ & $\mathrm{N}$ & $\mathrm{N}$ & $\mathrm{N}$ & $\mathrm{N}$ & $\mathrm{N}$ & $\mathrm{N}$ & $\mathrm{N}$ \\
\hline Travel associated/tourism $\ddagger \mathbb{I}$ & $11 / 42(26)$ & $1 / 7(29)$ & $\mathrm{N}$ & $\mathrm{Y}$ & $\mathrm{N}$ & $\mathrm{N}$ & $\mathrm{N}$ & $\mathrm{N}$ & $\mathrm{N}$ \\
\hline Professional exposure $\#$ & $2 / 42(5)$ & $0 / 7(0)$ & $\mathrm{N}$ & $\mathrm{N}$ & $\mathrm{N}$ & $\mathrm{N}$ & $\mathrm{N}$ & $\mathrm{N}$ & $\mathrm{N}$ \\
\hline Other exposure $\ddagger^{* *}$ & $0 / 42(0)$ & $1 / 7(29)$ & $\mathrm{N}$ & $\mathrm{N}$ & $\mathrm{N}$ & $\mathrm{N}$ & $\mathrm{Y}$ & $\mathrm{N}$ & $\mathrm{N}$ \\
\hline$\geq 1$ exposure & $14 / 42(33)$ & $3 / 7(43)$ & Y & $\mathrm{Y}$ & $\mathrm{N}$ & $\mathrm{N}$ & $\mathrm{Y}$ & $\mathrm{N}$ & $\mathrm{N}$ \\
\hline \multicolumn{10}{|c|}{$\begin{array}{l}\text { “Values are no. patients/total no. in category (\%) except as indicated. COVID-19, coronavirus disease; ICU, intensive care unit; LD, Legionnaires' disease. } \\
\text { †Demographics and outcome at the LD notification date. } \\
\text { †Elements indicated in mandatory LD notifications. LD risk exposures had to be reported if they occurred } \leq 14 \text { d before LD symptom onset. } \\
\text { §Exposures were indicated in LD mandatory notifications. } \\
\text { १Tाravel-associated/tourism exposures include hotels, holiday resorts, rental houses, and cruises. } \\
\text { \#Professional exposures include using public showers during work hours. } \\
\text { ** Other exposure: in-house plumbing. }\end{array}$} \\
\hline
\end{tabular}

were reported in case notifications for $3(43 \%)$ of 7 co-infected versus 14 (33\%) of 42 non-co-infected patients; the proportions of exposure sources reported was similar between the 2 groups. Despite the implementation on March 15 of the COVID-19 national lockdown in France, halting travel, 12 (24\%) of 49 exposures from the LD notifications were travel associated, a ratio similar to that in a 2017 report (9). Therefore, the decrease in LD cases observed in March 2020 cannot be explained by decreased travel.

Community-acquired LD and COVID-19 were diagnosed at hospital admission in 5 of 7 patients with both infections. For patient 2 (Table), whose symptoms started 48 hours before admission, UAT was not performed until 7 days after admission. Hospital-acquired COVID-19 was suspected in patient 3 because he initially tested negative but was positive after a 4 -week hospitalization (Figure 1). All 7 co-infected patients required admission to an intensive care unit (ICU; median stay 13 days,; range 2-34 days). In contrast, only 10 (32\%) of 31 of LD-positive/COVID-19-negative patients required ICU, similar to LD-only patients in previous reports (7).
At admission, all 7 co-infected patients had hyperthermia, 6 had cough or dyspnea, and 2 had neurologic symptoms. Five patients needed orotracheal intubation for a median of 13 days (range 3-30 days); acute respiratory distress syndrome developed in 4 patients, and 1 required extracorporeal membrane oxygenation (Figure 1). The median follow-up was 24 days (range $2-34$ days); 2 (29\%) of 7 patients died, similar to death rates for known ICU LD patients $(7,10)$ and severe COVID-19 patients $(8)$. Three $(7 \%)$ of 42 LD-positive/COVID-19-negative patients died, consistent with overall LD death rates (7). Patient 6 died within 3 days after co-infection diagnosis. Patient 3 had progressive pulmonary deterioration and died 6 days after COVID-19 diagnosis. First-line LD treatment was appropriate for all patients; 2 patients received COVID-19 treatment (Figure 1).

The longitudinal follow-up of patient 1 , a 71-year-old man receiving chemotherapy for multiple myeloma, may help decipher the kinetics of each pathogen load. Hospitalized for fever $\left(39^{\circ} \mathrm{C}\right)$ and productive cough, he required ICU admission on day 9 because of acute respiratory distress syndrome. A thoracic computed tomography scan found left lobar 


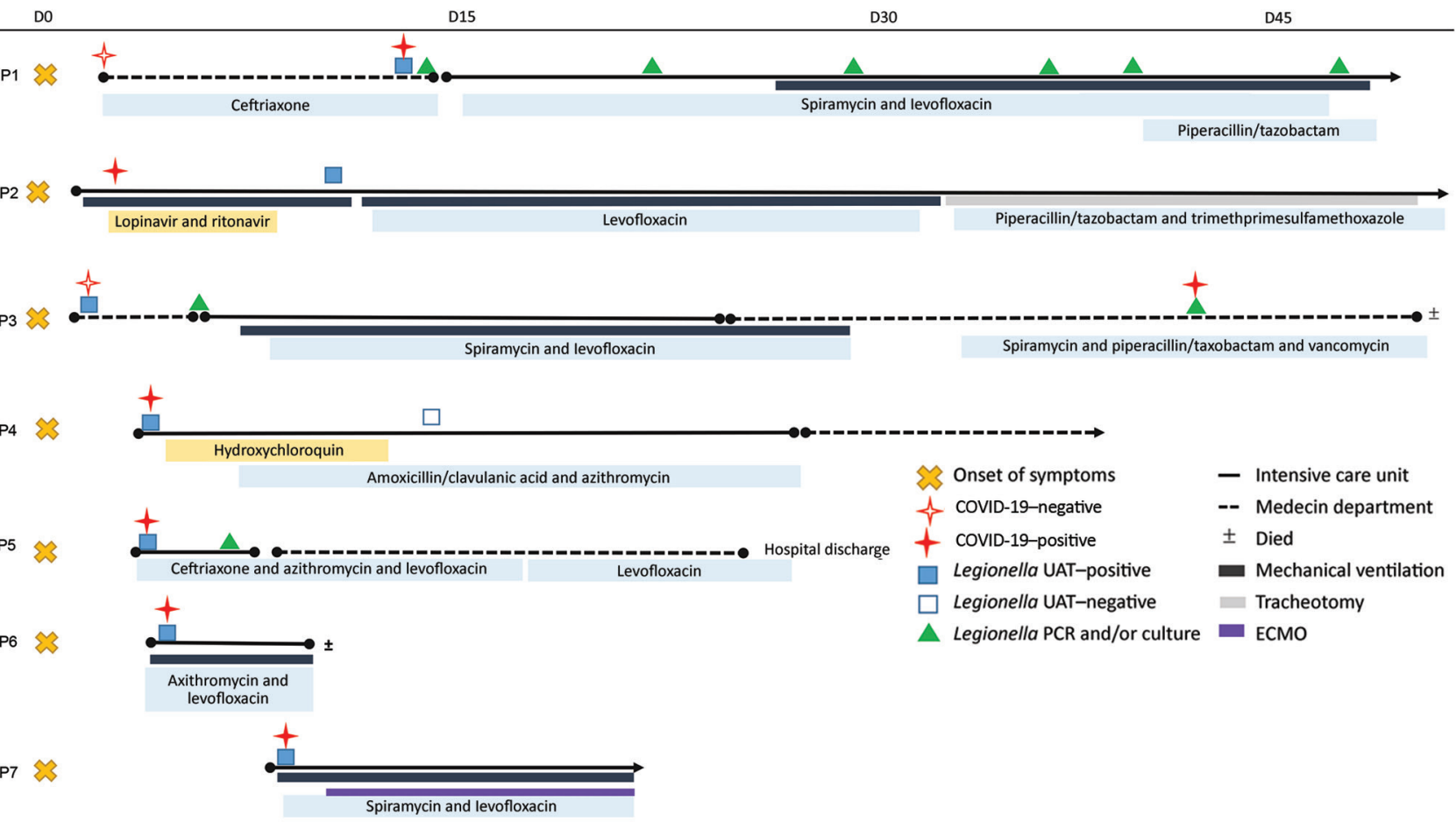

Figure 1. Timeline of first Legionnaires' disease symptoms among 7 Legionnaires' disease/COVID-19 co-infected patients, France, March 2020. COVID-19, coronavirus disease; D, day; ECMO, extracorporeal membrane oxygenation; UAT, urinary antigen test.

atelectasis, multiple ground-glass opacities compatible with COVID-19, and pleural effusion suggesting possible bacterial infection. Results of UAT and nasopharyngeal SARS-CoV-2 reverse transcription PCR were both positive. On day 10, a serum sample was PCR positive for both SARS-CoV-2 and Legionella (Figure 2, panel A); each pathogen has individually been associated with COVID-19 (11) and LD (12) severity. Beginning on day 10, longitudinal samples of the lower respiratory tract collected every 3-6 days showed a high SARS-CoV-2 viral load (7.5 $\log _{10}$ RNA copies/100 cells), followed by a decrease to 1.3 $\log _{10}$ RNA copies/100 cells within 21 days (Figure 2, panel B). In contrast, lung Legionella DNA load increased and remained high (cycle threshold 21.9) until day 31 . To identify potential bacterial co-infections, we performed a lung microbiota analysis on a D19 bronchoalveolar lavage using 16S MinION long-read sequencing technology (Oxford Nanopore Technologies, https://nanoporetech.com). Similar to another study of LD microbiomes (13), we found a predominance of Legionella (61\%) and the presence of commensal lung bacteria (Appendix Figure, https://wwwnc.cdc.gov/EID/article/27/11/20-

Figure 2. Timeline of detection of SARS-CoV-2 and Legionella in patient 1, a 71-year-old man receiving chemotherapy for multiple myeloma, France, March 2020. A) Serum Legionella DNA load estimated by qPCR $\mathrm{C}_{\mathrm{t}}$ and SARS-CoV-2 RNA load expressed as the number of $\log _{10}$ RNA copies/mL serum. B) Pulmonary Legionella DNA load estimated
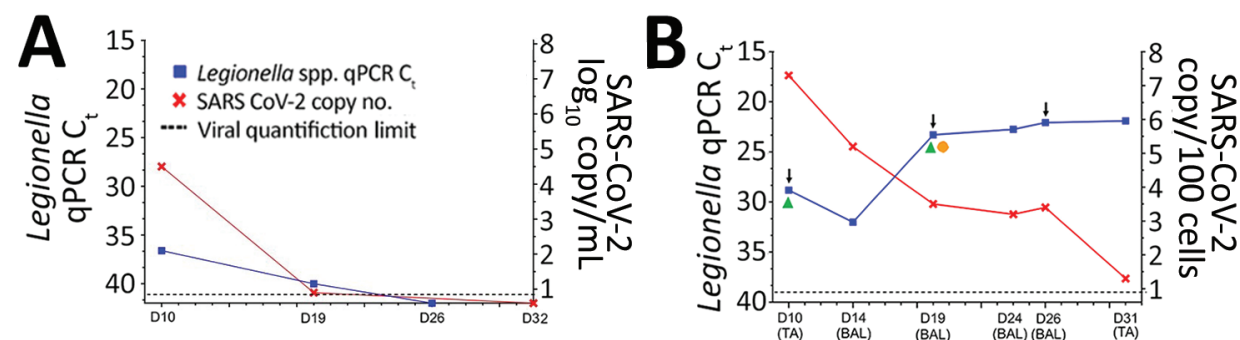

by qPCR $C_{t}$, targeting the 16sRNA gene (R-DiaLeg, Diagenode, https://www.diagenode.com) and SARS-CoV-2 RNA load (Institut Pasteur, Paris protocol). Arrows indicate dates of computed tomography scans, green triangles indicates dates of positive Legionella cultures, and orange circle indicates date of lung microbiome testing. Values are normalized according to cellular quantification using the CELL Control r-gene kit (bioMérieux, https://www.biomerieux.com) and expressed as the number of log 10 RNA copies/100 cells from pulmonary TA and BAL. BAL, broncho-alveolar lavage; $C_{t}$, cycle threshold; $D$, days after onset of symptoms; qPCR, quantitative PCR; SARS-CoV-2, severe acute respiratory syndrome coronavirus 2; TA, tracheal aspirations. 
2150-App1.pdf) but no additional bacterial co-infection. On day 26, while high lung Legionella DNA load persisted, a third chest scan found pseudocavitation. Persistence of culture or PCR positivity in respiratory samples, or both, has been described in patients with Legionella lung abscesses, especially if immunocompromised (14).

\section{Conclusions}

Our study found a substantial proportion of patients in LD notifications in France during March 2020, mostly elderly men with underlying conditions, also had COVID-19. They required ICU admission more frequently and had a higher case-fatality rate than patients without SARS-CoV-2 co-infection, but these rates were similar to that for all ICU-admitted LD patients $(7,10)$. Overall, health effects from co-infections were more severe than from single infections, perhaps because of cumulative effects or because patients with co-infections may be more likely to have risk factors associated with poor outcomes. Another possibility is that SARS-CoV-2 infection may be more severe in this population.

Longitudinal monitoring of a single co-infected patient found a first phase of predominant SARS$\mathrm{CoV}-2$ replication followed by a resurgence of Legionella and worsening of respiratory symptoms while SARS-CoV-2 decreased. Initial viral infection could establish pulmonary damage suitable for the bacteria to develop, similar to how bacterial superinfections develop in influenza-infected patients (15). Such co-infections may lead to poor prognoses as demonstrated here and elsewhere (3), underlining the importance of extensive screening for respiratory pathogens in patients with suspected or confirmed COVID-19. Because Legionella and other pulmonary microorganisms share clinical and radiological features with SARS-CoV-2 infection, they should be included in COVID-19 differential diagnoses (3).

Members of the COVID-19 diagnosis HCL consortium: Antonin Bal, Geneviève Billaud, Grégory Destras, Vanessa Escuret, Sibyle Etievant, Emilie Frobert, Florence Morfin, and Clément Munier

\section{Acknowledgments}

We thank all clinicians, microbiologists, and epidemiologists for providing clinical, laboratory, and epidemiologic data: Florent Wallet, Christelle Fabbro, Claire Plassart, Dominique Jusserand, Patricia Stroessel, Julie Kieffer, Agnes Scanvic, Carole Guillemet, Sarah Bassous, Arthur Luton, Christian Meyer, and Catherine Maine. We thank the authors, the originating and submitting laboratories for their sequence data and metadata shared through the Global Initiative on Sharing All Influenza Data (GISAID; https://www.gisaid.org) on which this research is based. We also thank Philip Robinson and Hélène Boyer for help in manuscript preparation.

According to legislation in France all patients have been fully informed of the project and of their right to decline participation in the study and written informed consent from patient 1 was obtained. The local ethics committee approved the study (number 20-57; Comité d'Ethique du CHU de Lyon).

\section{About the Author}

Dr. Allam is a medical biologist at the French National Reference Centre for Legionella at the Infective Agents Institute, North Hospital Network, in Lyon, France, and teaches bacteriology at the Claude Bernard Lyon 1 Medical University. She is seeking a $\mathrm{PhD}$ with a concentration in Legionella virulence and severity factors.

\section{References}

1. Spiteri G, Fielding J, Diercke M, Campese C, Enouf V, Gaymard A, et al. First cases of coronavirus disease 2019 (COVID-19) in the WHO European Region, 24 January to 21 February 2020. Euro Surveill. 2020;25:2000178. https:/ /doi.org/10.2807/1560-7917.ES.2020.25.9.2000178

2. Hughes S, Troise O, Donaldson H, Mughal N, Moore LSP. Bacterial and fungal coinfection among hospitalized patients with COVID-19: a retrospective cohort study in a UK secondary-care setting. Clin Microbiol Infect. 2020;26:1395-9. https://doi.org/10.1016/j.cmi.2020.06.025

3. Lai C-C, Wang C-Y, Hsueh P-R. Co-infections among patients with COVID-19: The need for combination therapy with non-anti-SARS-CoV-2 agents? J Microbiol Immunol Infect. 2020;53:505-12. https:/ / doi.org/10.1016/ j.jmii.2020.05.013

4. Arashiro T, Nakamura S, Asami T, Mikuni H, Fujiwara E, Sakamoto S, et al. SARS-CoV-2 and Legionella co-infection in a person returning from a Nile cruise. J Travel Med. 2020;27:taaa053.

5. Bordi L, Nicastri E, Scorzolini L, Di Caro A, Capobianchi MR, Castilletti C, et al.; On Behalf Of Inmi Covid-Study Group And Collaborating Centers. Differential diagnosis of illness in patients under investigation for the novel coronavirus (SARS-CoV-2), Italy, February 2020. Euro Surveill. 2020;25:2000170. https:/ / doi.org/10.2807/ 1560-7917.ES.2020.25.8.2000170

6. Verhasselt HL, Buer J, Dedy J, Ziegler R, Steinmann J, Herbstreit F, et al. COVID-19 Co-infection with Legionella pneumophila in 2 tertiary-care hospitals, Germany. Emerg Infect Dis. 2021;27:1535-7. https:/ / doi.org/10.3201/ eid2705.203388

7. Chidiac C, Che D, Pires-Cronenberger S, Jarraud S, Campèse C, Bissery A, et al.; French Legionnaires' Disease Study Group. Factors associated with hospital mortality in community-acquired legionellosis in France. Eur Respir J. 2012;39:963-70. https:/ / doi.org/10.1183/09031936.00076911

8. Boëlle P-Y, Delory T, Maynadier X, Janssen C, Piarroux R, Pichenot M, et al. Trajectories of hospitalization in COVID-19 
patients: an observational study in France. J Clin Med. 2020; 9:3148. https://doi.org/10.3390/jcm9103148

9. Beauté J; The European Legionnaires' Disease Surveillance Network. Legionnaires' disease in Europe, 2011 to 2015. Euro Surveill. 2017;22:30566 [Erratum in: Euro Surveill. 2017; 22:171116-1]. https://doi.org/10.2807/1560-7917. ES.2017.22.27.30566

10. Cecchini J, Tuffet S, Sonneville R, Fartoukh M, Mayaux J, Roux D, et al. Antimicrobial strategy for severe communityacquired Legionnaires' disease: a multicentre retrospective observational study. J Antimicrob Chemother. 2017;72: 1502-9. https://doi.org/10.1093/jac/dkx007

11. Rao SN, Manissero D, Steele VR, Pareja J. A systematic review of the clinical utility of cycle threshold values in the context of COVID-19. Infect Dis Ther. 2020;9:573-86 [Erratum in: Infect Dis Ther. 2020;9:587]. https://doi.org/10.1007/ s40121-020-00324-3

12. van de Veerdonk FL, de Jager CPC, Schellekens JJA, Huijsmans CJJ, Beaumont F, Hermans MHA, et al. Legionella pneumophila DNA in serum samples during Legionnaires' disease in relation to C-reactive protein levels. Eur J Clin Microbiol Infect Dis. 2009;28:371-6. https://doi.org/10.1007/ s10096-008-0638-8
13. Pérez-Cobas AE, Ginevra C, Rusniok C, Jarraud S, Buchrieser C. Persistent Legionnaires' disease and associated antibiotic treatment engender a highly disturbed pulmonary microbiome enriched in opportunistic microorganisms. MBio. 2020;11:e00889-20. https://doi.org/ 10.1128/mBio.00889-20

14. Pouderoux C, Ginevra C, Descours G, Ranc A-G, Beraud L, Boisset S, et al. Slowly or nonresolving Legionnaires' disease: case series and literature review. Clin Infect Dis. 2020;70:1933-40. https:/ / doi.org/10.1093/ cid/ciz538

15. Small C-L, Shaler CR, McCormick S, Jeyanathan M, Damjanovic D, Brown EG, et al. Influenza infection leads to increased susceptibility to subsequent bacterial superinfection by impairing NK cell responses in the lung. J Immunol. 2010;184:2048-56. https://doi.org/10.4049/ jimmunol.0902772

Address for correspondence: Sophie Jarraud, Centre National de Reference des Legionella, Institut des Agents Infectieux, Hospices Civils de Lyon, 103 Grande rue de la Croix Rousse, 69317 Lyon CEDEX 04, France; email: sophie.jarraud@chu-lyon.fr

\section{EID Podcast: \\ Tracking Canine Enteric Coronavirus in the UK}

Dr. Danielle Greenberg, founder of a veterinary clinic near Liverpool, knew something was wrong. Dogs in her clinic were vomiting - and much more than usual. Concerned, she phoned Dr. Alan Radford and his team at the University of Liverpool for help. Before long they knew they had an outbreak on their hands.

In this EID podcast, Dr. Alan Radford, a professor of veterinary health informatics at the University of Liverpool, recounts the discovery of an outbreak of canine enteric coronavirus.

Visit our website to listen: https://go.usa.gov/xsMcP EMERGING INFECTIOUS DISEASES 